\title{
PULMONARY TUBERCULOSIS: RELATIONSHIP BETWEEN SPUTUM BACILLOSCOPY AND RADIOLOGICAL LESIONS(1)
}

\author{
Mauro GOMES(2), Roberto SAAD Jr.(2) \& Roberto STIRBULOV(2)
}

\section{SUMMARY}

OBJECTIVES: To determine the frequency of radiological manifestations of chest tuberculosis among the tuberculosis outpatients at the Santa Casa de Misericórdia de São Paulo Hospital, and to correlate these radiological findings with the sputum bacilloscopy.

SAMPLE AND METHODS: A review was made of the medical record cards and chest X-rays of all patients attended between January 1996 and December 1998. Patients with a diagnosis of tuberculosis who presented intrathoracic manifestations of the disease and negative anti-HIV serology were selected.

RESULTS: The selection included 153 patients, with an average age of 37.5 years, who were predominantly male (60.8\%) and white (56.9\%). Pulmonary lesions were present in 121 (79.9\%) and extrapulmonary lesions in 32 (20.1\%). Parenchymal-infiltrate lesions appeared in 56 patients $(36.6 \%)$, cavity lesions in $55(36.0 \%)$, pleural effusion in $28(18.3 \%)$, isolated nodules in $6(3.9 \%)$, mediastinal enlargement in $4(2.6 \%)$ and miliary pattern in $4(2.6 \%)$. Cavities were present in $45.5 \%$ of the patients with pulmonary lesions, generally in association with the parenchymal-infiltrate lesions. Parenchymal infiltrate was present in $86.8 \%$ of the patients with pulmonary lesions. There was significant presence of alcohol-acid resistant bacillus in the sputum of patients with cavities (76.4\%), in comparison with those without cavities $(50 \%)(\mathrm{p}=0.003)$.

CONCLUSIONS: Parenchymal-infiltrate lesions are the most frequent radiological manifestation of pulmonary tuberculosis, and they are generally associated with cavities. There is a relationship between the presence of acid fast bacilli in sputum and pulmonary cavity lesions.

KEYWORDS: Tuberculosis; Pulmonary tuberculosis; Bacilloscopy; Radiology; Mycobacterium tuberculosis.

\section{INTRODUCTION}

The identification of the tubercle bacillus by Robert Koch, in 1882, in association with the discovery of X-rays by Wilhelm Conrad Roentgen, in 1895 , were fundamental milestones in understanding the natural history and diagnosis of tuberculosis. Nonetheless, a series of studies has demonstrated that no radiographic image can be considered to be absolutely specific for the disease: so much so that all attempts at establishing a universally accepted radiological classification have failed ${ }^{31}$.

Chest radiography is the best predictor of tuberculosis ${ }^{5,29}$. Familiarity with the various radiological manifestations is fundamental for achieving early diagnosis and a reduction in morbidity ${ }^{15}$. Radiography presents high sensitivity for diagnosis, despite its low specificity ${ }^{1,2,16,19,29}$. This may have been the reason why the First Brazilian Tuberculosis Consensus made the affirmation that the radiological criterion, in the final analysis, provides the most objective data for diagnosing of probability ${ }^{25}$.
According to the Manual of Norms for Tuberculosis Control and the First Brazilian Tuberculosis Consensus, bacilloscopy should be prioritized as a diagnostic method. In addition to its high specificity, this method allows individuals infected with the bacillus to be discovered. These people are the most important source of infection ${ }^{25}$.

Enormous value has been placed on bacteriological studies, on the basis of the World Health Organization's policy of encouraging the discovery of patients through their respiratory symptoms, initially via examination of the sputum. Such valuation has come in for criticism in our environment. The stance of putting diagnostic suspicions based on radiology into second position deserves to be reviewed, according to some people, in view of the new realities brought in by HIV and multi-drug resistance ${ }^{2}$. There are those who say that radiography is the ideal initial diagnosis method, due to its simplicity and noninvasiveness ${ }^{26}$.

(1) "Dissertação de Mestrado", December 2001.

(2) Faculdade de Ciências Médicas da Santa Casa de São Paulo, São Paulo, SP, Brasil

Correspondence to: Mauro Gomes, Rua Dr. Zuquim 449, conj. 74, 02035-010 São Paulo, SP, Brasill, Fax: 55.11.6973-2440, E-mail: gomesm@uol.com.br 
The detection and cure of individuals infected with the bacillus are essential elements in the control of tuberculosis ${ }^{25,31}$. Familiarity with the various aspects of the radiological manifestations, in association with performing bacilloscopy on the sputum, allows for early diagnosis and rapid establishment of treatment. With this in mind, our objective was to determine the frequency of radiological manifestations of tuberculosis among the tuberculosis outpatients at the Pneumology Clinic of the Department of Medicine of the Santa Casa de Misericórdia de São Paulo Hospital, and to correlate these radiological manifestations with positive findings from direct bacilloscopy on the sputum.

\section{SAMPLE AND METHOD}

A review was made of the medical record cards and chest X-rays of all patients attended at the tuberculosis outpatient service of the Pneumology Clinic of the Department of Medicine of the Santa Casa de Misericórdia de São Paulo Hospital during the period from January 1996 to December 1998. Patients with a diagnosis of tuberculosis who presented intrathoracic manifestations of the disease and negative antiHIV serology were selected.

The criteria considered for a sure diagnosis of tuberculosis were the presence of sputum with positive direct bacilloscopy (by Ziehl Neelsen technic) or an anatomopathological examination that was compatible with tuberculosis (the demonstration of caseating granulomas or acidfast bacilli in tissue specimens). The lung tissue fragments used in the anatomopathological study were obtained by means of transbronchial biopsy. For situations with isolated nodules, the material was obtained by means of thoracotomy or videothoracoscopy.

Patients with three negative sputum samples or incapable of expectorating, and with an inconclusive anatomopathological examination, were considered to be within the diagnosis of probable tuberculosis.

The criteria considered for the diagnosis of probable tuberculosis were: 1) clinical criteria (coughing for more than four weeks, evening fever, night sudoresis and weight loss); 2) suggestive radiography. For there to be a diagnosis of probable tuberculosis, it was considered that there would have to be the presence of at least two clinical criteria in association with the radiological criterion.

When pleural tuberculosis was suspected, a thoracocentesis evaluation was made, in association with a pleural biopsy using a Cope needle. For a sure diagnosis, the pleural fragment needed to have anatomopathological characteristics of tuberculosis. For a diagnosis of probable tuberculosis, the exsudate pleural liquid was evaluated and it needed to have a lymphocyte cell predominance of more than $80 \%$ and an adenosine deaminase assay of more than $40 \mathrm{U} / \mathrm{l}$.

For a diagnosis of tuberculosis in mediastinal lymph nodes, a lymph node fragment obtained by biopsy via mediastinoscopy needed to have anatomopathological characteristics of tuberculosis.

Patients were selected for this study only when they had a diagnosis of probable tuberculosis and also presented a positive response to specific therapy for tuberculosis (therapeutic test).
It was of interest to the study that the initial chest radiography was performed in the posterior-anterior position for each patient, and this was related in time to the collection of sputum for the bacilloscopy study.

The radiological alterations found were divided into six groups: 1) pulmonary infiltrate; 2) pulmonary cavity; 3) miliary pattern; 4) mediastinal lymph node enlargement; 5) pleural effusion; 6) pulmonary nodule.

The term pulmonary infiltrate was used to describe irregular and coarse opacities areas in the lungs that were linear or non-linear and dispersed throughout the lungs, not necessarily in a homogenous pattern (Fig. 1). Cavities were defined as uniloculate or multiloculate delimited gaseous collections with individualized walls, which could be single or multiple (Fig. 2). When there was an association between pulmonary infiltrate and cavities, the latter was considered to be the principal manifestation. Miliary pattern was defined as nodular opaque areas in the lungs, of one to three millimeters in diameter, dispersed uniformly throughout the pulmonary parenchyma (Fig. 3). Mediastinal lymph node enlargement was considered to be present when abnormal densities and/ or widening of the mediastinum appeared (Fig. 4). Pleural effusion was defined when the costophrenic angle appeared to be shallow or deleted from the chest radiography. Pulmonary nodules were considered to be present when there were single circular opacity areas of up to three centimeters in diameter (Fig. 5).

Data relating to 197 patients were analyzed. At a later stage, 44 of them were excluded because their diagnoses could not be established, or they did not present an intrathoracic manifestation of tuberculosis, or they had a positive anti-HIV result.

The sample was submitted to statistical evaluation via the Spearman Correlation Analysis for all pairs of variables, with a significance level of 5\%. The statistical program utilized was the Statistical Package for Social Sciences, version 6.0 (SPSS-6.0).

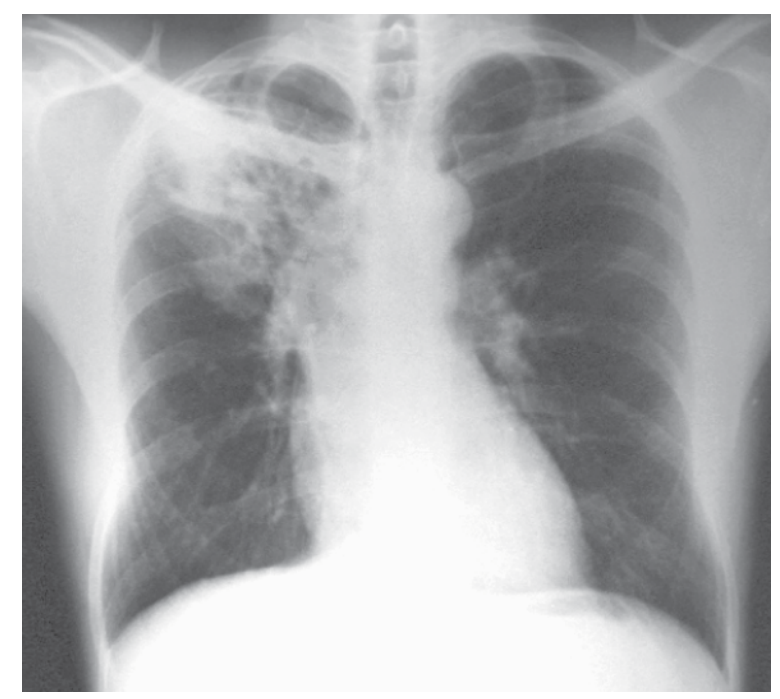

Fig. 1 - Posterior-anterior chest radiography demonstrating pulmonary infiltrate in the upper right lobe (Patient No. 7). 


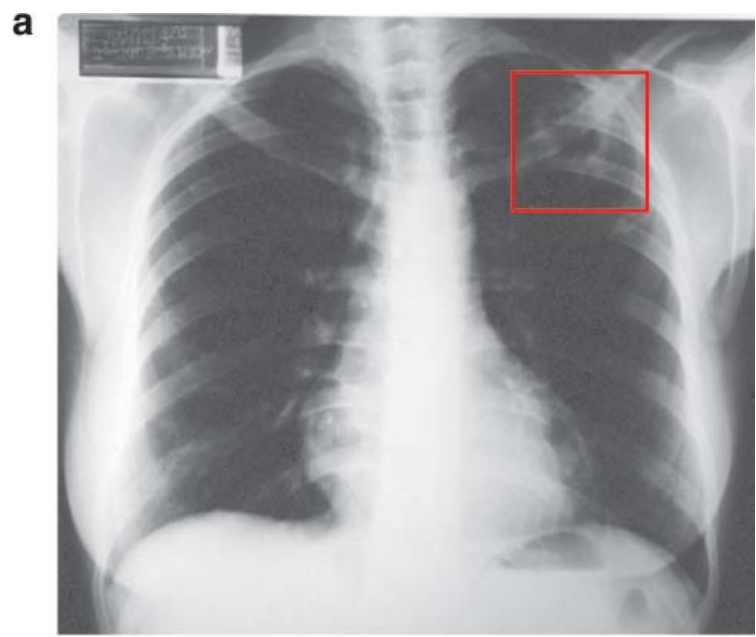

b

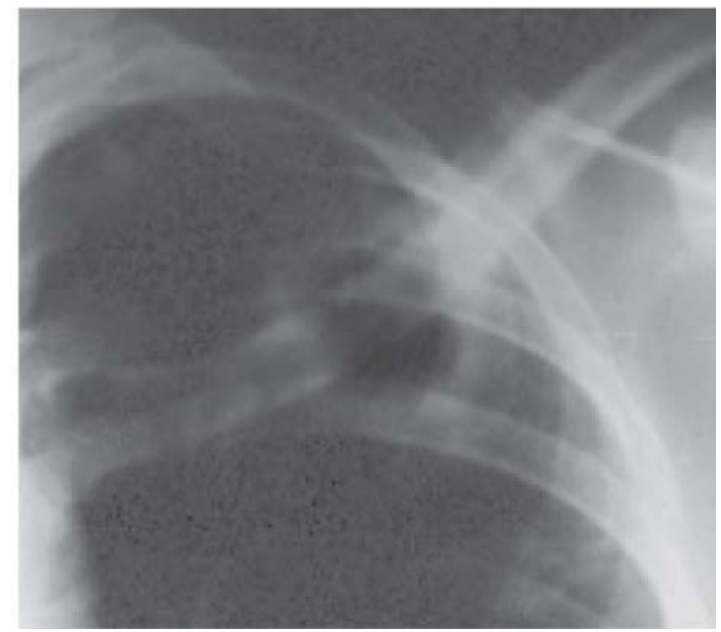

Fig. 2 - a) Posterior-anterior chest radiography demonstrating cavity in the upper left lobe. b) Detail of cavitary lesion (Patient No. 131).

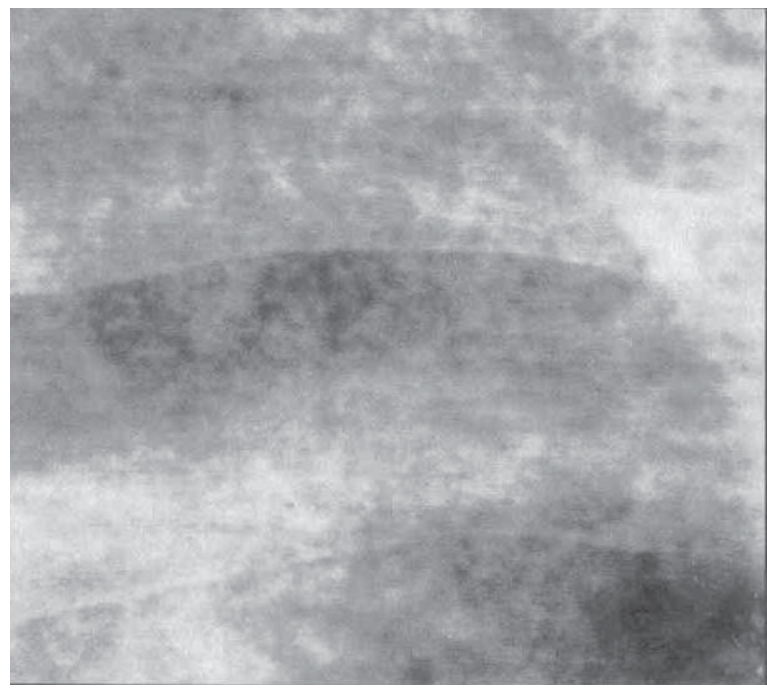

Fig. 3 - Chest radiography demonstrating miliary pattern - detail (Patient No. 90).

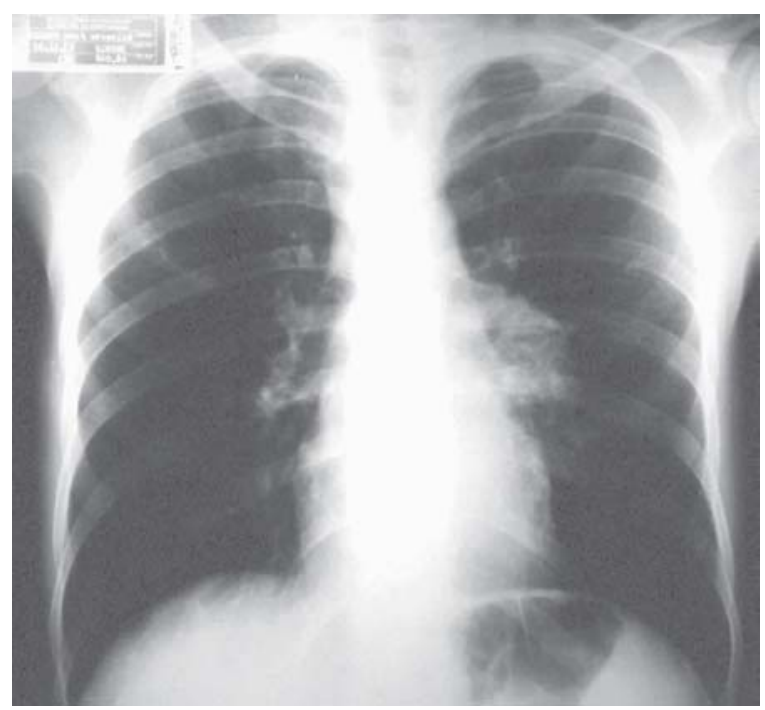

Fig. 4 - Posterior-anterior chest radiography demonstrating mediastinal lymph node enlargement (Patient No. 89).

a
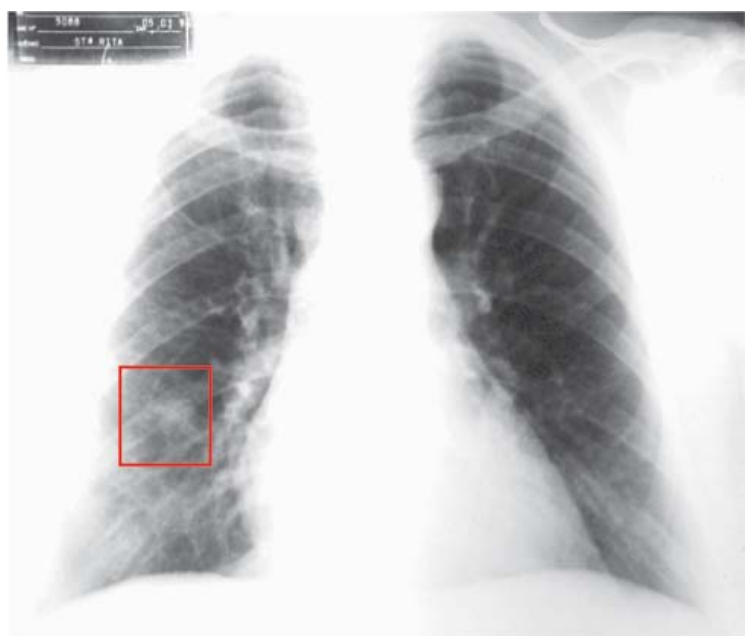

b

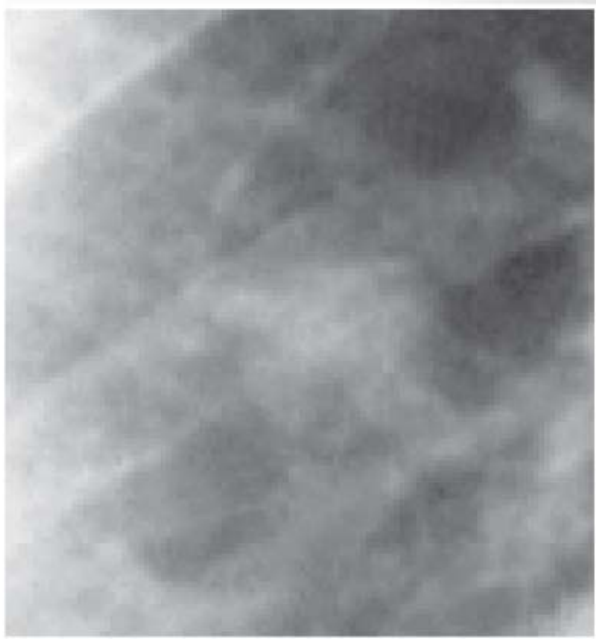

Fig. 5 - a) Posterior-anterior chest radiography demonstrating isolated nodule in the right lung; b) Detail of nodule (Patient No. 38). 


\section{RESULTS}

One hundred and fifty-three patients were included in the study. Their ages ranged from 13 to 80 years, with an average of 37.5 years and median of 36.0 years. There were 93 males $(60.8 \%)$ and 60 females $(39.2 \%)$, and $87(56.9 \%)$ were white and $66(43.1 \%)$ non-white.

One hundred and twenty-one patients $(79.1 \%)$ presented pulmonary lesions: cavity and/or pulmonary infiltrate, isolated nodules or miliary pattern. In 32 patients (20.9\%), the disease involved the chest without evidence of compromised lungs, i.e. pleural effusion or mediastinal lymph node enlargement were presented. The distribution of the frequencies of radiographic alterations is to be found in Table 1.

Considering the presence of cavities, excluding those with the extrapulmonary lesions, cavity lesions were present in $45.5 \%$ of the patients with pulmonary lesions. Only six patients (3.9\%) presented cavity manifestations, without concomitant infiltrate.

Considering presence of pulmonary infiltrate that accompanied the cavity lesions, we found that 105 patients $(68.6 \%)$ of our sample had the

\section{Table 1}

Distribution of the frequencies of radiographic alterations and the respective percentages

\begin{tabular}{lcc}
\hline Radiographic alterations & Frequency & Percentage \\
\hline Pulmonary infiltrate & 56 & 36.6 \\
Cavity & 55 & 36.0 \\
Pleural effusion & 28 & 18.3 \\
Isolated nodule & 6 & 3.9 \\
Mediastinal lymph node enlargement & 4 & 2.6 \\
Miliary pattern & 4 & 2.6 \\
TOTAL & 153 & 100.0 \\
\hline
\end{tabular}

SOURCE: Pneumology Clinic (tuberculosis outpatient service), Department of Medicine of the Santa Casa de Misericórdia de São Paulo Hospital. presence of pulmonary infiltrate. Excluding those with extrapulmonary lesions, alterations of infiltrate type appeared in $86.8 \%$ of the patients with pulmonary lesions.

A sure diagnosis was achieved in 127 patients (83.0\%), via bacilloscopy in 75 cases $(49.0 \%)$ and via anatomopathological study in 52 cases $(34.0 \%)$. The presumptive diagnosis was made in the remaining 26 cases $(17.0 \%)$.

The distribution of the pulmonary lesions according to the bacilloscopy is to be found in Table 2. From the study of the bacilloscopy in the pulmonary lesions, the sputum demonstrated the presence of acidfast bacilli in $76.4 \%$ of the patients with cavities and $50.0 \%$ of those without cavities $(\mathrm{p}=0.003)$. There was a correlation between positive bacilloscopy and the pulmonary cavity lesions. A summary of the results obtained is to be found in Fig. 6.

\section{DISCUSSION}

There is no proof that tuberculosis preferentially affects one sex rather than the other, but our results and the majority of authors describe greater

Table 2

Distribution of the pulmonary lesions according to the bacilloscopy, with the respective percentages

\begin{tabular}{lccccc}
\hline $\begin{array}{l}\text { Pulmonary } \\
\text { Lesions }\end{array}$ & Cavity & Infiltrate & Miliary & Nodule & Total \\
\hline Negative & 13 & 24 & 3 & 6 & 46 \\
bacilloscopy & $(23.6 \%)$ & $(42.9 \%)$ & $(75.0 \%)$ & $(100.0 \%)$ & $(38.0 \%)$ \\
Positive & 42 & 32 & 1 & - & 75 \\
bacilloscopy & $(76.4 \%)$ & $(57.1 \%)$ & $(25.0 \%)$ & & $(62.0 \%)$ \\
TOTAL & 55 & 56 & 4 & 6 & 121 \\
& $(100.0 \%)$ & $(100.0 \%)$ & $(100.0 \%)$ & $(100.0 \%)$ & $(100.0 \%)$ \\
\hline
\end{tabular}

SOURCE: Pneumology Clinic (tuberculosis outpatient service), Department of Medicine of the Santa Casa de Misericórdia de São Paulo Hospital.

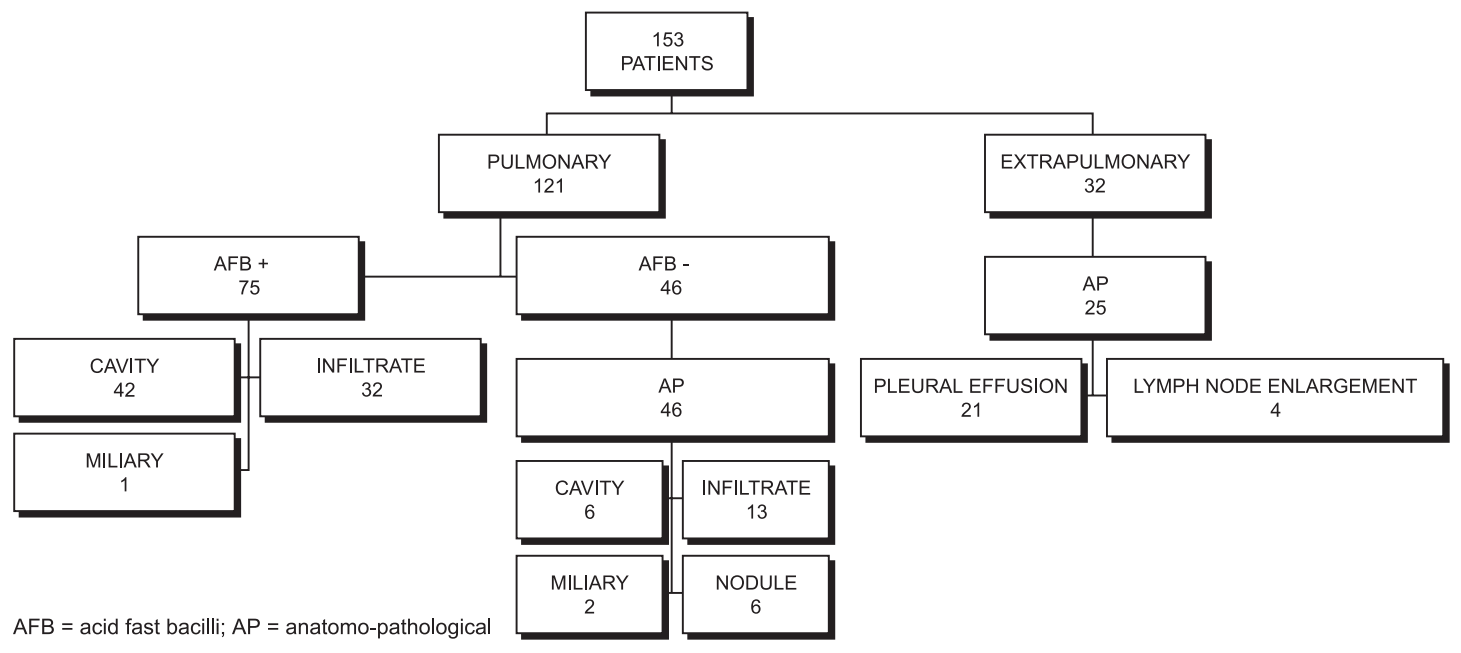

Fig. 6 - Summary of the results obtained. 
incidence among males ${ }^{18}$. Despite this, we did not find any correlation between the radiographic manifestation and the sex $(p=0.705)$. We also observed that the disease preferentially affected the under-40 age group and predominantly whites $(56.9 \%)$ over non-whites $(43.1 \%)$.

We found pulmonary lesions in $79.1 \%$ of the patients. In the remainder, there was chest involvement without evidence of compromised lungs.

Among the pulmonary lesions, pulmonary infiltrate was our most common finding. Even though exclusively infiltrative lesions appeared in only $36.6 \%$ of the patient total, when cavity lesions accompanied by concomitant infiltrate are considered, pulmonary infiltrate was present in $68.6 \%$. Excluding those with chest involvement but without pulmonary lesions, infiltrate reached a presence of $86.8 \%$ in the patients with pulmonary lesions. It therefore constitutes the principal radiographic manifestation in pulmonary tuberculosis in our experience.

AKTOGU et al. also reported that pulmonary infiltrate was the most common radiographic alteration, being shown in $99.0 \%$ of the 5094 patients in their series ${ }^{3}$.

The presence of cavities is the most important radiographic finding in tuberculosis, as it is considered to be the mark of the disease among adults $^{28}$. The appearance rate for cavity lesions varies greatly in the literature, with reports of appearing in 40.0 to $87.0 \%$ of adults at some point during the course of the disease $e^{3,4,6,8,12,13,14,17,22,23,30,32}$. Going against the majority of authors, NYMAN et al. found cavities in only $13.9 \%$ of their 215 patients ${ }^{27}$.

In Brazil, MACEDO et al. have described the presence of cavities in $74.7 \%$ of a series of 158 cases of pulmonary tuberculosis ${ }^{20}$, which is a high figure in comparison with ours. In our experience, cavities were the predominant radiological manifestation in $36.0 \%$ of our patients. This corresponded to $45.5 \%$ of the patients with pulmonary lesions, concording with the majority of authors. It needs to be emphasized that a finding of cavities alone was rare in our issue (3.9\%), and this type of lesion was generally associated with infiltrate-type alterations of the pulmonary parenchyma.

We did not find any pulmonary cavities with an air-liquid level. The presence of an air-liquid level is considered to be unusual in tuberculosis ${ }^{12,24}$, although this alteration has been demonstrated in 9 to $21 \%$ of tuberculosis cavities ${ }^{9,14,21}$.

Despite the fact that miliary tuberculosis occurs more commonly in the primary form of the disease, it may be encountered in up to $7 \%$ of post-primary occurrences ${ }^{3,17,22,24,32,33}$. The largest findings of the miliary form have been described by NYMAN et al., corresponding to $12.0 \%$ of their 214 patients with pulmonary lesions ${ }^{27}$.

In our findings, the miliary pattern represented $2.6 \%$ of the total, equivalent to $3.3 \%$ of the patients with the pulmonary form. All of these cases were in patients aged over 40 years. The correlation of this alteration with the age was not statistically significant because of the small number of patients with the miliary form.

KWONG et al., studying 71 patients with miliary disease, concluded that radiography allowed the identification of $59.0 \%$ to $69.0 \%$ of the cases, with high inter-observer specificity $(97.0 \%-100.0 \%)^{19}$. Nevertheless, the sensitivity was not shown to be so high, since in $14.0 \%$ of the cases the diagnosis was only made at the necropsy. The radiography may be normal in miliary tuberculosis, probably because the classical miliary pattern only appears six weeks after the hematogenic dissemination $^{6,22}$. In Brazil, CORREA et al. retrospectively studied 30 patients interned with the miliary form and concluded that, in the majority of cases, the lesions were bilateral and symmetrical and that in $10 \%$ of them the initial radiography did not present lesions ${ }^{10}$.

The diagnosis of miliary tuberculosis tends to be difficult, since the bacilloscopy and sputum culture are often negative. Invasive procedures, usually transbronchial biopsy, are generally necessary for the diagnostic confirmation $^{6,18}$.

CORREA et al. found negative bacilloscopy in $76.9 \%$ of 26 patients with the miliary pattern ${ }^{10}$. However, WILCKE et al. found positive bacilloscopy in $57.0 \%$ and a positive culture in $100.0 \%$ of their seven patients, but the significance of their findings was limited by the size of their sample ${ }^{32}$.

In our series, which involved a total of four patients with miliary tuberculosis, a sure diagnosis was given in two of these cases by the transbronchial biopsy, while in another it was via bacilloscopy. In one case a probable diagnosis was established.

The nodular form constitutes one of the less common forms of tuberculosis in adults, and it may calcify over time. GONZÁLEZARENAS et al. considered that its incidence rate was up to $2 \%{ }^{13}$. This frequency has only been confirmed by WILCKE et al., who reported this tuberculoma in $0.5 \%$ of 548 patients $^{32}$. KHAN et al. encountered tuberculomas in $9 \%$ of 88 patients with pulmonary tuberculosis ${ }^{17}$. CHOYKE et al. found six cases (5.8\%) of tuberculoma among 103 cases, but their sample consisted of adults with primary tuberculosis ${ }^{7}$. In the series of NYMAN et al., this finding corresponded to $7 \%$ of 214 cases $^{27}$. In our study, $3.9 \%$ of the cases were in the nodular form, which was equivalent to $5 \%$ of the patients with pulmonary tuberculosis.

In the series of KHAN et al., which involved a total of eight cases of tuberculoma, the diagnosis was made by means of bronchoscopy in only two cases, with the need for thoracotomy for diagnostic confirmation in the remaining six $\operatorname{cases}^{17}$. CHOYKE et al. made the diagnosis after thoracotomy in $100.0 \%$ of their six patients ${ }^{7}$. For WILCKE et al., the diagnosis was made via sputum culture in two out of a total of three cases $^{32}$. In our sample, the diagnosis of all the nodular forms came via the surgical route, after either thoracotomy or videothoracoscopy. This finding was similar to what was obtained by CHOYKE et al. ${ }^{7}$, but not statistically significant because of the small number of patients with isolated nodule in the sample.

Chest involvement without evidence for compromised lungs occurred in $21.0 \%$ of our sample, with a predominance of pleural effusion $(87.5 \%)$ over mediastinal lymph node enlargement $(12.5 \%)$.

The finding of lymph node enlargement in the mediastinum corresponded to $2.6 \%$ of the total of our sample. This was similar to what was described by WILCKE et al., who reported this alteration in 
$2.5 \%$ of 548 patients $^{32}$. In our study, there was no concomitance of lymph node enlargement and pulmonary lesion, which corroborates KRITSKI et al., who affirmed that this association was not common among patients with negative anti-HIV serology ${ }^{18}$.

Contrary to these results, NYMAN et al. found that mediastinal lymph node enlargement was the principal manifestation of chest tuberculosis without lung involvement. These authors described chest lesions outside of the lungs in $20.0 \%$ of 503 cases: mediastinal lymph node enlargement $(64.8 \%)$, pleural effusion $(24.1 \%)$, pericardial effusion (7.4\%) and tracheal involvement $(3.7 \%)^{27}$.

We did not find the same similarity between our results and those obtained by WILCKE et al. ${ }^{32}$ in relation to pleural effusion. For them, pleural effusion was responsible for only $0.2 \%$ of their 504 cases $^{32}$, while among our patients effusion was found in $18.3 \%$ of the cases. Our finding resembles what was obtained by BONADIO et al., who reported effusion in $17.4 \%$ of 88 patients 4 .

Normal radiography of the chest does not exclude the existence of lung tuberculosis in symptomatic individuals. The disease may be restricted to the proximal airways or have a focal character with lesions that are too small to be recorded on film ${ }^{14,23,27,33}$, which may occur in 3 to $5 \%$ of the cases ${ }^{24}$. WILCKE et al. diagnosed tuberculosis in three patients with normal radiography out of $548(0.5 \%)$, with high-resolution chest tomography being useful in these $\operatorname{cases}^{32}$. In our experience, we have not found any patient with lung tuberculosis whose radiography was normal.

The recovery of the bacillus from secretions and tissue of suspected patients confirms the diagnosis of tuberculosis. Despite sputum bacilloscopy being easy to do and cheap, the imprecision of tuberculosis diagnoses in Brazil is worrying. In our country, according to the First Brazilian Tuberculosis Consensus, sputum bacilloscopy was not performed for around $16.0 \%$ of the patients treated for pulmonary lesions. Also, in $22.0 \%$ of the pulmonary cases, the treatment was instituted despite negative bacilloscopy, thus resulting in a total of $38.0 \%$ of lung tuberculosis patients treated without bacteriological confirmation. These numbers are even higher when data from the State of São Paulo are observed. There, the total number of lung tuberculosis cases treated without bacteriological confirmation is around $43.0 \%{ }^{25}$.

In 21.0 to $26.6 \%$ of cases, the bacilloscopy may be negative for lung tuberculosis ${ }^{12,14,23}$. These figures are lower than ours, in which $38.0 \%$ of the patients with pulmonary lesions presented negative bacilloscopy. In these cases, the anatomopathological study was fundamental for the diagnosis in $58.7 \%$ of them. Considering all the pulmonary cases, a sure diagnosis was achieved in $84.3 \%$, and in only $15.7 \%$ of the cases was the therapeutic regime instituted with a probable diagnosis. We consider these figures to be significant in relation to the Brazilian data mentioned earlier, with regard to diagnostic precision.

In our series, when studying the bacilloscopy in the cases of pulmonary lesions, the sputum was positive in $76.4 \%$ of the patients with cavities and $50.0 \%$ of those without cavities, which was a significant difference $(\mathrm{p}=0.003)$. Thus, we have observed a correlation between positive bacilloscopy and the type of radiographic alteration, with the presence of acid-fast bacilli being significant in the cases of pulmonary cavity lesion. These findings resemble those obtained by WILCKE et al., who demonstrated positive bacilloscopy in $89 \%$ of the patients with cavities, in contrast to only $58 \%$ positivity for the cases without cavities $(\mathrm{p}<0.05)^{32}$.

The difference observed between these groups is important, since patients whose bacilloscopy is negative are considerably less infectious than those with positive bacilloscopy. Because the latter expel greater quantities of bacilli, it can be said that these individuals have greater importance from an epidemiological point of view ${ }^{31}$.

The positivity of the sputum in cases of cavity lesions obtained in our study is close to what would be expected for patients with cavities. KRITSKI et al. obtained positive sputum in $80.0 \%$ of cavity cases ${ }^{18}$, although the First Brazilian Tuberculosis Consensus places the expectation at around $90.0 \%$.

The correlation between positive bacilloscopy and pulmonary cavity lesion also suggests that, in the diagnostic investigation of patients who present cavities via radiography and negative bacilloscopy, new procedures must be performed, even invasive ones, in order to discard diagnoses other than tuberculosis.

In conclusion, pulmonary infiltrate formed the most common radiographic manifestation of lung tuberculosis among our population at the tuberculosis outpatient service of the Pneumology Clinic of the Department of Medicine of the Santa Casa de Misericórdia de São Paulo Hospital. Cavity lesions rarely appeared alone, and were generally associated with infiltrate-type lesions of the pulmonary parenchyma. Pleural effusion, isolated lung nodules, mediastinal lymph node enlargement and miliary pattern were less common manifestations. There was a relationship between the presence of acid-fast bacilli in the sputum and the pulmonary cavity lesions.

\section{RESUMO}

\section{Tuberculose pulmonar: relação entre baciloscopia do escarro e lesões radiológicas}

OBJETIVOS: Determinar a freqüência das manifestações radiológicas da tuberculose nos pacientes do Ambulatório de Tuberculose do Departamento de Medicina da Santa Casa de Misericórdia de São Paulo, e correlacionar a manifestação radiológica e a baciloscopia direta do escarro.

CASUÍSTICA E MÉTODOS: Foram revisados os prontuários e as radiografias de tórax de todos os doentes atendidos entre janeiro/ 1996 e dezembro/1998. Foram selecionados os doentes com diagnóstico de tuberculose e que apresentavam manifestação intratorácica da doença e sorologia anti-HIV negativa.

RESULTADOS: Foram incluídos 153 doentes, média de 37,5 anos, predominância do sexo masculino $(60,8 \%)$ e da raça branca $(56,9 \%)$. Lesões pulmonares estavam presentes em 121 (79,1\%); no restante ocorreu envolvimento torácico sem comprometimento pulmonar. Alterações do tipo infiltrado pulmonar ocorreram em $56(36,6 \%)$, cavidade em 55 (36,0\%), derrame pleural em 28 (18,3\%), nódulo isolado em $6(3,9 \%)$, linfonodomegalia mediastinal em 4 (2,6\%) e padrão miliar 

2003.

em $4(2,6 \%)$. Excetuando-se as lesões extrapulmonares, cavidades estiveram presentes em $45,5 \%$ dos doentes com lesões pulmonares. Considerando o infiltrado pulmonar que acompanhou a lesão cavitária, em 105 (68,6\%) o infiltrado esteve presente. Excluindo-se aqueles com lesões extrapulmonares, o infiltrado apareceu em $86,8 \%$ dos doentes com lesões pulmonares. Baciloscopia foi positiva em $76,4 \%$ dos doentes com cavidade e em 50,0\% dos sem cavidade $(\mathrm{p}=0,003)$.

CONCLUSÕES: O infiltrado pulmonar constitui-se na manifestação radiográfica mais freqüente da tuberculose pulmonar, estando a cavidade geralmente associada às lesões do tipo infiltrado pulmonar. Existe relação entre a presença de BAAR no escarro e as lesões cavitárias pulmonares.

\section{REFERENCES}

1. AFIUNE, J.B. - Avanços no diagnóstico da tuberculose. In: CUKIER, A.; NAKATANI, J. \& MORRONE, N. Pneumologia: atualização e reciclagem. São Paulo, Editora Atheneu, 1998. v. 2, p. 234-238.

2. AFIUNE, J.B. \& IDE NETO, J. - Diagnóstico da tuberculose pulmonar escarro negativo. J. Pneumol., 19: 37-41, 1994.

3. AKTOGU, S.; YORGANCIOGLU, A.; ÇIRAK, K.; KOSE, T. \& DERELI, S.M. - Clinical spectrum of pulmonary and pleural tuberculosis: a report of 5480 cases. Europ. resp. J., 9: 2031-2035, 1996.

4. BONADIO, M.; SPITALERI, P.; GIGLI, C. et al. - Current epidemiological and clinical aspects of tuberculosis: a study in the Hospital of Pisa. Recenti Progr. Med., 91: $347-351,2000$.

5. BRANDLI, O. - The clinical presentation of tuberculosis. Respiration, 65: 97-105, 1998

6. BUCKNER, C.B. \& WALKER, C.W. - Radiologic manifestations of adult tuberculosis. J. thorac. Imag., 5: 28-37, 1990.

7. CHOYKE, P.L.; SOSTMAN, H.D.; CURTIS, A.M. et al. - Adult-onset pulmonary tuberculosis. Radiology, 148: 357-362, 1983.

8. CHRISTENSEN, E.E.; DIETZ, G.W.; AHN, C.H. et al. - Initial roentgengraphic manifestations of pulmonary Mycobacterium tuberculosis, M. kansasii and $M$. intracellularis infections. Chest, 80: 132-136, 1981.

9. COHEN, J.R.; AMOROSA, J.K. \& SMITH, P.R. - The air-fluid level in cavitary pulmonary tuberculosis. Radiology, 127: 315-316, 1978.

10. CORREA, J.C.; ANDRADE, J.N.; ROMANO, S.E.; CORREA, V.L.F. \& BORGES, A.L.F. - Alterações do radiograma torácico na tuberculose miliar. J. Pneumol., 18(supl. 2): 117, 1992.

11. CORREA, J.C.; ANDRADE, J.N.; ROMANO, S.E.; CORREA, V.L.F. \& BORGES, A.L.F. - Diagnóstico bacteriológico na tuberculose miliar. J. Pneumol., 18(supl. 2): $117,1992$.

12. FRASER, R.G.; PARÉ, J.A.P. \& PARÉ, P.D. - Diagnosis of diseases of the chest. 3. ed. Philadelphia, W.B. Saunders, 1991. p. 882-932.

13. GONZÁLEZ-ARENAS, C.I.; GAVIRIA, A.Z.; MURO, G.H. et al. - Nódulos pulmonares múltiples como manifestación inusual de la tuberculosis pulmonar. Descripción de tres casos. Rev. clín. esp., 191: 44-46, 1992.

14. HADLOCK, F.P.; PARK, S.K.; AWE, R.J. \& RIVERA, M. - Unusual radiographic findings in adult pulmonary tuberculosis. Amer. J. Roentgenol., 134: 1015-1018, 1980.
15. HARISINGHANI, M.G.; McLOUD, T.C.; SHEPARD, J.A. et al. - Tuberculosis from head to toe. Radiographics, 20: 449-470, 2000.

16. HLAWATSCH, A.; KAUCZOR, H.U. \& THELEN, M. - Pulmonary tuberculosis - the current radiological diagnosis of an old disease. Radiologe, 40: 507-517, 2000.

17. KHAN, M.A.; KOVNAT, D.M.; BACHUS, B. et al. - Clinical and roentgengraphic spectrum of pulmonary tuberculosis in the adult. Amer. J. Med., 62: 31-38, 1977.

18. KRITSKI, A.L.; CONDE, M.B. \& SOUZA, G.R.M. - Tuberculose: do ambulatório à enfermaria. 2. ed. São Paulo, Atheneu. 2000.

19. KWONG, J.S.; CARIGNAN, S.; KANG, E.Y.; MULLER, N.L. \& FITZGERALD, J.M. - Miliary tuberculosis. Diagnostic accuracy of chest radiography. Chest, 110: 339342, 1996.

20. MACEDO, L.G.; AFIUNE, J.B. \& MELO, F.A.F. - Características clínicas, radiológicas e bacteriológicas de pacientes portadores de tuberculose pulmonar (um estudo simples, oportuno e atual). J. Pneumol., 18(supl. 2): 118, 1992.

21. MARANJUOLA, D. - Fluid levels in pulmonary tuberculosis cavities in a rural population of Nigeria. Amer. J. Roentgenol., 141: 519-520, 1983.

22. McADAMS, H.P.; ERASMUS, J. \& WINTER, J.A. - Radiologic manifestations of pulmonary tuberculosis. Radiol. Clin. N. Amer., 33: 655-678, 1995.

23. MILLER, W.T. \& MacGREGOR, R.R. - Tuberculosis: frequency of unusual radiographic findings. Amer. J. Roentgenol., 130: 857-875, 1978.

24. MILLER, W.T. \& MILLER JUNIOR, W.T. - Tuberculosis in the normal host: radiological findings. Semin. Roentgenol., 28: 109-118, 1993.

25. MINISTÉRIO DA SAÚDE/CENEPI/FNS/SBPT - I Consenso Brasileiro de Tuberculose. J. Pneumol., 23: 279-342, 1997.

26. MORRONE, N.; CONDE, M.; FAZOLO, N.; SOARES, L.C.P. \& FERES, W.J.M. Abreugrafia e exame de escarro no diagnóstico da tuberculose: considerações sobre 1026 pacientes diagnosticados pela primeira vez. J. Pneumol., 6: 152-158, 1980.

27. NYMAN, R.S.; BRISMAR, J.; HUGOSSON, C.; LARSSON, S.G. \& LUNDSTEDT, C. - Imaging of tuberculosis: experience from 503 patients. I. Tuberculosis of the chest. Acta radiol. (Stockh.), 37: 482-488, 1996.

28. PRATT, P.C. - Pathology of tuberculosis. Semin. Roentgenol., 14: 196-203, 1979.

29. SCOTT, B.; SCHMID, M. \& NETTLEMAN, D. - Early identification and isolation of inpatients at high risk for tuberculosis. Arch. intern. Med., 154: 326-330, 1994.

30. SPENCER, D.; YAGAN, R.; BLINKHORN, R. \& SPAGNUOLO, P.J. - Anterior segment upper lobe tuberculosis in the adult: occurrence in primary and reactivation disease. Chest, 97: 384-388, 1990.

31. TOMAN, K. - Case-finding. In: Tuberculosis case-finding and chemotherapy: questions and answers. Washington, World Health Organization, 1979. p. $1-72$.

32. WILCKE, J.T.R.; ASKGAARD, D.S.; NYBO JENSEN, B. \& DOSSING, M. Radiographic spectrum of adult pulmonary tuberculosis in a developed country. Resp. Med., 92: 493-497, 1998.

33. WOODRING, J.H.; VANDIVIERE, H.M.; FRIED, A.M. et al. - Update: the radiographic features of pulmonary tuberculosis. Amer. J. Roentgenol., 146: 497-506, 1986.

Received: 14 October 2002

Accepted: 28 August 2003 